2016-09-30

\title{
Outsider Positions: Negotiating Gender, Nationality and Memory in the War Writing of Enid Bagnold
}

Smith, Angela

http://hdl.handle.net/10026.1/6575

10.1080/09699082.2016.1232507

Women's Writing

Taylor \& Francis

All content in PEARL is protected by copyright law. Author manuscripts are made available in accordance with publisher policies. Please cite only the published version using the details provided on the item record or document. In the absence of an open licence (e.g. Creative Commons), permissions for further reuse of content should be sought from the publisher or author. 


\section{Outsider Positions: Negotiating Gender, Nationality and Memory in the War Writing of Enid Bagnold}

\section{Angela K. Smith}

To cite this article: Angela K. Smith (2016): Outsider Positions: Negotiating Gender, Nationality and Memory in the War Writing of Enid Bagnold, Women's Writing, DOI: 10.1080/09699082.2016.1232507

To link to this article: http://dx.doi.org/10.1080/09699082.2016.1232507

Published online: 30 Sep 2016.

Submit your article to this journal ¿

Q View related articles $\longleftarrow$

View Crossmark data $־$ 


\title{
OUTSIDER POSITIONS: NEGOTIATING GENDER, NATIONALITY AND MEMORY IN THE WAR WRITING OF ENID BAGNOLD
}

\author{
Angela K. Smith
}

School of Humanities and Performing Arts, Plymouth University, Plymouth, UK

\begin{abstract}
In 1918, Enid Bagnold published A Diary Without Dates, a revealing book that kept few secrets about life in a wartime hospital. Bagnold's book has helped the construction of the mythology of disillusionment that has clouded memory of the First World War for a century. In 1920, Bagnold published The Happy Foreigner, a novel that is much less easy to categorize. As her protagonist, Fanny, drives across the derelict battlefields of France, she reflects on the ways in which those battlefields may be recalled in later cultural memory. However, there is a curious optimism in Fanny that is quite at odds with these later constructions of disillusionment. France in 1919 is a melting pot of different people, military and civilian, men and women, representing many different nations as the first understandings of memory crystallize. This essay explores Bagnold's two war books in terms of the ways in which she negotiates gender and nationality. What does it mean to be a woman in a hospital? How do different nationalities interact in the post-war landscape, questioning these myths of disillusionment before they are even constructed? By considering these outsider positions, the author argues that Bagnold's role in helping to shape the memory of the First World War is far more complex than it might at first appear.
\end{abstract}

\section{Women's war writing and memory}

In this essay, I will explore the ways in which the outsider positions of gender and nationality can enhance our contemporary understanding of the First World War. By focusing specifically on the war writings of Enid Bagnold, built around the experience of women and infused with multiple different voices, I will argue that there are other ways of remembering-alternate dimensions to cultural memory that do not conform to the grand narratives of the war. One hundred years after its outbreak, the ways in which we remember the First World War are still significantly shaped by the literature of the period. Dominant in this myth-making were the writers of the trenches-Wilfred Owen, Siegfried Sassoon, Robert Graves and 
others-ensuring that the images of trench warfare have come to embody the war in cultural memory. ${ }^{1}$ Rosa Maria Bracco suggests that " $[\mathrm{t}]$ he predominant memory of most narratives of disillusion is the burden of extreme suffering of one generation". ${ }^{2}$ However, for decades, feminist scholars have been arguing against the exclusivity of this memory, ${ }^{3}$ broadening our perspectives of the war to include the experience of others-non-combatants and women. But arguably, even where they have succeeded in bringing women into the public view, again most commonly through their literary texts, these women have often been seen to contribute to the overall accepted, predominantly negative understanding of the war. That is the myth of disillusionment which originates in the trenches and then filters out to colour our impressions of the whole of post-war society.

The most acclaimed women writers of the First World War-those who have perhaps had the biggest impact on centenary commemorations, such as Vera Brittain-are often interpreted as integral contributors to the construction of this myth. Others, such as Mary Borden, Irene Rathbone and Enid Bagnold, although less well known, are equally influential. Their tales of the trauma of wartime nursing and loss appear to tessellate perfectly with the accounts of their male contemporaries, feeding a cultural memory that determines to construct the war and its legacy in negative terms. Christine Hallett has recently addressed this, arguing that the Voluntary Aid Detachment member (VAD), in particular,

[...] becomes the stereotypical victim-heroine, whose courage enables her to "stick" to her duties, whose kindness and humanity makes her the patients' favourite "nurse", and whose intelligence permits her, finally to offer a truly reflective account of her experiences. She is, in fact, the female counterpart of those brave young men, the "Lions led by Donkeys", who marched across no-man's-land to almost-certain destruction on the orders of foolish and callous officers. ${ }^{4}$

Women who volunteered for war work produced written records of their experiences in the years that followed the war which have been interpreted to endorse all the accepted suffering and sacrifice of the war. Borden's 1928 collection of fragments and stories, The Forbidden Zone, recreates moments of suffering in front-line hospitals that continue to shock due to the linguistic power and modernist detachment of her prose. Ellen La Motte's earlier Backwash of War (1916) is similarly powerful. Rathbone's 1932 novel We That Were Young represents the varied experiences of a group of young women, their hope and future prospects as a consequence of the war, and project this loss onto the following decade. But I wish to argue here that some women's writing does not fit comfortably into this mythology. In particular, the war writing of Enid Bagnold, while engaging head-on with the suffering and trauma, also explores alternative aspects of the experience of both the 
war and its immediate legacy. Marianne Hirsch and Valerie Smith have argued that "what culture remembers and what it chooses to forget are intricately bound up with issues of power and hegemony, and thus with gender". 5 Our cultural memory has absorbed much of what Bagnold has to say about life in a wartime hospital, particularly where it fits in with the established myths of male experience. However, Bagnold's interpretation of women's experience and racial interaction in her war books contributes to a very different strand of memory, allowing us to explore the legacy of the war in a fresh light. I will explore Bagnold's two war books in terms of the ways in which she negotiates gender and nationality. What does it mean to be a woman in a hospital or on the abandoned battlefields of France? How do different nationalities, the winners and the losers, interact in the post-war landscape, questioning these myths of disillusionment before they are even constructed? By considering these outsider positions, I shall argue that Bagnold's role in helping to shape our memory of the First World War is far more complex than it might at first appear.

In 1918, Enid Bagnold was dismissed from her position as $\mathrm{VAD}$ at the Royal Herbert Hospital, Woolwich, following the publication of her $A$ Diary Without Dates, a revealing book that kept few secrets about life in the wartime hospital. It was based on her own experiences as a VAD and, in its pages, Bagnold addresses many of the traumas of hospital life for the male patients, as well as for the women who surround them. Although Bagnold's book has contributed to the construction of the mythology of disillusionment that dominates memory of the war for us a century on, there are glimpses of a different kind of spirit in Bagnold's writing that refuses to comply absolutely with the myth. Her negativity operates to produce a clear picture of the war, but it is also one that suggests mechanisms for dealing with the trauma. In late 1918, Bagnold went to France as a member of the First Aid Nursing Yeomanry (FANY) to drive for the French army. This experience formed the basis of her second war book, The Happy Foreigner-a novel that appears to be much less easy to categorize. As her protagonist, Fanny, drives across the derelict battlefields of France, she does reflect on the ways in which those battlefields would be recalled in later cultural memory. However, there is a curious optimism in Fanny that is quite at odds with these later constructions of disillusionment. On the one hand, as a woman in what remains a man's world, she represents a gendered outsider, refusing to comply with any real stereotypes. At the same time, France in 1919 is a melting pot of different people, military and civilian, men and women, representing many different nations as the first understandings of memory crystallize. As Santanu Das has noted: "The war also resulted in an unprecedented range of interracial and cross-cultural encounters, experiences and intimacies". 6 And Claire Buck argues that "Bagnold uses Fanny's encounters with racialized others as she drives across the Western Front to situate 
Europe as a geopolitical space in need of reimagining". 7 Many outsiders coming together without the buffer of war begin to ask questions about the ways in which memory will develop.

In recent years, some historians of the First World War and its legacy have begun to make a strong case in opposition to the dominant myth of disillusionment. Adrian Gregory has argued that " $\mathrm{t}]$ he Armistice on 11 November 1918 was greeted with joy. The end of the war was far more genuinely popular than its beginning", refuting the notion of a shattered community unable to see an optimistic future. ${ }^{8}$ He goes on to argue that the culture of disillusionment built on a shared experience of loss, which dominates our understanding of the post-war world, does not accurately reflect society:

Depictions of Britain in the 1920s as a traumatized society with a shattered sense of itself, should be understood for what they are: constructions to cover up a much more complex social reality of winners and losers, continuities and changes. ${ }^{9}$

Janet S. K. Watson concurs: "The history of the war was being recast through the power of memory, and critics selectively identified the texts at the center of the debate. This story of disillusionment was created retrospectively". ${ }^{10}$ This is a view shared by Gary Sheffield, who argues that while the literatures of war in the post-war world present the anguished veteran, they did not actually reflect the real experience of the population:

Thus we have a paradox. Clearly the intellectual and literary climate of the late twenties and early thirties was largely one of disenchantment with the First World War. Equally clearly, for large numbers of Britons disenchantment was at best skin deep, and some did not share this view at all. ${ }^{11}$

Bagnold's war books, which predate the boom in war literature by nearly a decade, begin to suggest this ambiguity. Alongside the trauma, there is hope. Woven through the hardship is liberation, particularly for the woman who is prepared to take the opportunities presented to her. As Watson notes: "For many women, as well as many men, the war was a transformative experience that shaped their self-identities for the rest of their lives". ${ }^{12}$

\section{Liberation in A Diary Without Dates}

A Diary Without Dates has attracted a lot of critical attention, not least because Bagnold adopts a rather experimental narrative style and structure, adapting many tropes of modernist writing to allow her to articulate the unspeakable side of hospital life. ${ }^{13}$ It is quite literally a diary without dates, shaped around the changing seasons as the protagonist (Bagnold) progresses in her work at the Woolwich hospital. She begins her work as a VAD "outside the glass doors", wrapped in the domestic work of the hospital. Later she moves "inside the glass doors" to carry out the menial work on the officers' 
ward. Finally, she is moved to a ward for ordinary soldiers to work with "the boys". As she moves through the hospital, always on the lowest rung of the hierarchical ladder, she exposes the impact of class segregation, the stoic suffering of the wounded and the inability of even the trained nurses to deal with the pressure of army-hospital life. Her dismissal from the hospital in itself emphasizes the perceived negative impact of the book on the morale of a nation after four years of war.

While all these aspects of the book do contribute to the legacy of disillusionment, there are other elements of the narrative that, like Bagnold herself, refuse to conform. Perhaps most prominent is the way that Bagnold explores gender. The complexities of interpreting gender in the First World War, particularly in relation to nurses, have been explored in detail elsewhere. ${ }^{14}$ As Janet Lee has put it: "femininity must be recognized as a contested site of meaning". ${ }^{15}$ Indeed, this is exactly what Bagnold does in her war writing, starting in 1918 with nurses. Here, to be a woman can mean uniformity: "a slim white figure in white approaches, dwarfed by the smoky distance; her nun-like cap floating, her scarlet cape, the 'cape of pride', slipped round her shoulders". 16 The professional nurses with whom Bagnold works are "unsexed" by their position, detached from an emotional response that would be crushing if acknowledged, and protected by the language of euphemism: "The sister came out and told me she thought he was 'not up to much'. I think she means he is dying" (7). Their appearance is designed to reinforce the façade of steely professionalism, thus enabling them to function when faced with the continual stream of horrific wounds. Gender becomes almost obsolete beneath the structures of these coping mechanisms:

The hospital-a sort of monotone, a place of whispers and wheels moving on rubber tyres, long corridors, and strangely unsexed women moving in them. Unsexed not in any real sense, but the white clothes, the hidden hair, the stern white collar just above the chin, give them an air of school-girlishness, an air and a look women don't wear in the world. They seem unexpectant. (31)

The hospital, embodied by the women who populate it, is set apart from the senses. It is "monotone", without variation of sound, and silent, apart from the swishing of the "rubber tyres" of the trolleys and whispered voices, refuting the anguished voices of the injured soldiers. It is monochrome, black and white, refusing to acknowledge the vivid reds, blues, greens and yellows of the wounded body. All the individual characteristics of the women are hidden from view, giving them a protective anonymity and infantilizing them as though to devolve responsibility for the suffering around them. They are without sex, without gender, otherworldly, expecting nothing.

The VADs share these characteristics to some extent. Bagnold notes: "I see already manifested in them the ardent longing to be alike" (30). But, for her, and so perhaps by default for all the women, this uniformity is double-edged, 
holding a promise of freedom that is unobtainable in the outside world, where she must be judged as a woman. She begins the book with this sentiment: "I like discipline. I like to be part of an institution. It gives one more liberty than is possible among three or four observant friends" (3). This immediately sets the more subversive tone of liberation that is woven through the whole narrative, threaded through the structures of hospital life and celebrated in the natural world that continues to exist just outside the hospital doors.

In the hospital, Bagnold can escape from the restrictions of gender and class that structure her life outside. However critical she may be of the structures of the institution, they offer her a personal space that enables reflection. This is realized in her enjoyment of some of the most menial tasks, which allow her to observe and get to know the men for whom she cares:

Just as I like the unending laying of the trays in the corridor, so making splints appears to me a gentle work in which one has the time to look at and listen to the ward with more penetrating eyes, with wider ears. (92)

The splints make her "very happy" (104) in the opportunities they offer for contemplation, observation and a quiet personal freedom. Unlike the nurses alongside whom she works, the men are all individuals with names and personalities far beyond their wounds. In some other nursing narratives, ${ }^{17}$ the men are often identified only with their wounds, a narrative technique that emphasizes the anonymity of the combat soldier and therefore the sacrifice and dehumanization that contribute to the legacy of disillusionment. But Bagnold's soldiers have distinct personalities. In some cases, these personalities are directly linked to their wounds, but for others, such as the workingclass boy Pinker, no specific wound is mentioned at all. His personality is built through his desire to help and tease his comrades, and his previous life related during the intervals of splint-making. Despite this development of character in the men, they lack the innate liberty of the uniformed women, for they cannot leave.

The exuberant way in which Bagnold conjures the outside world, interlaced with the monochrome of the hospital throughout, lifts the tone of the text, making the overall message of war experience much more ambivalent than might be expected. "I must put down the beauty of the night" (10), she writes when still "outside the glass doors", recording the clear moon of the autumn night as she walks home. "Shall I ever grow out of that excitement over the first bit of snow" (32) heralds winter for the reader, catching a mood of exhilaration that cannot be crushed by hospital life. As she records Christmas in the ward, outside it she notes: "I was excited by the strange and silent fog" (37). The outside world, the weather and the seasons offer her the opportunity to weave a subversive thread throughout the narrative: "I walked out of the hospital into a gale, clouds driving to the sea, trees bending back and fore across the moon. I walked till I was warm, and then 
I walked for happiness" (46). The text is filled with these asides, creeping in between the more sinister representations of the wounded and the hardships of hospital life, like a rebellious subtext that refuses to be ignored. When combined with the genderless uniformity of the nursing experience, outside of the public gaze, they offer the narrator Bagnold a further space for liberation.

This is developed from the inside by Bagnold's use of flower imagery and the domestic within the space of the ward. An elderly lady visitor to the "Tommies" ward leaves single roses with her religious messages for each man. The splashes of colour offend the nurses and VADs, threatening the monochrome of the hospital. "But life talks differently.... Pinker said, 'Makes the po'r ole lady 'appy!'” (97). By emphasizing the ways in which the nurses and the soldiers see things differently, Bagnold is able to articulate multiple perspectives on the war. This antipathetic juxtaposition is seen elsewhere. In spring, the sisters decorate their bunks with rambler roses and larkspur, apparently a clandestine statement of their femininity. However, they are not unique: "But the love of decoration is not woman's alone. Through the dispensary hatchway I saw three empty poison-bottles, each with a poppy stuck in its neck" (98). There is an irony here. The poppy, that indestructible weed of no-man's-land, has infiltrated the dispensary. Placed in the empty "poison-bottles", they seem to bring the battlefield into the heart of the hospital. But set against the roses and larkspur of the sisters, they become symbols of the domestic and the female, embedded in the masculine domain of the pharmacists, and complicating our reading of the hospital spaces.

\section{Gender and multiculturalism in The Happy Foreigner}

Bagnold's use of imagery in A Diary Without Dates suggests an interesting blurring of gender roles, which is reinforced by the asexuality of her nurses and the nurturing behaviour of some of her soldier patients. But in her 1920 novel The Happy Foreigner, Bagnold takes her exploration a stage further. In her 1986 biography of Bagnold, Anne Sebba notes that all the main events of the novel actually occurred in Bagnold's own life, suggesting that this post-war work may have been a liberating experience. ${ }^{18}$ The Happy Foreigner follows its protagonist, Fanny, on a journey of self-discovery, not only contemplating gender roles in the post-war world and the ongoing construction of memory, but also exploring the complex issues of nationality in a world where the state of war no longer dictates how people should relate to one another. Stella Deen has argued that The Happy Foreigner deserves a place in the recognized canon of women's war literature precisely because it engages with so many important issues. She suggests that "[e]ven while The Happy Foreigner registers the gendered and national boundaries that under-write war and that govern social life in the war zone, it foregrounds 
a set of experiences shared by men and women, ally and enemy". ${ }^{19}$ It is the presentation of these shared experiences that enables Bagnold to contribute to the construction of cultural memory in more controversial ways.

The British women of the FANY occupy a unique place in the post-war landscape, not least because they have chosen to be there rather than been conscripted, like most of the soldiers they encounter. Their presence turns established order upside down, and they embody a disruption to accepted gender patterns. Lee argues that "unlike many other female auxiliaries, they were militarized and saw themselves as female soldats with a history of service alongside male combatants". ${ }^{20}$ Fanny illustrates this when she is assigned to drive a Russian colonel to Verdun. He is at first reluctant to trust his journey to a woman. The men of other nations also find the idea of a young, single, unchaperoned woman difficult to contemplate: "What kind of women can these be whose men allow them to drive alone with us for hours, and sometimes days?"21 These anxieties impact on Fanny, for a time shaking her confidence in her own role and leaving her bewildered. But as the novel progresses, her professional conduct wins over her critics, and she emerges unapologetic to claim her place in the landscape.

Fanny's own response to her gender role is ambiguous. She is dressed in khaki and considers herself very unfeminine, but this uniform secures her pioneering position in the war zone, which has excluded women for years. Like the nurses in A Diary Without Dates, she occupies a curious middle groundunfeminine, even asexual, as a uniformed driver, yet a woman nonetheless and as such very different from her clients. Susan Grayzel argues that " $[\mathrm{u}]$ niformed women's efforts to assert that they were directly participating in the war were constantly undermined by a rhetoric that claimed that women's, even military women's, main contribution was to serve the men serving the nation". ${ }^{22}$ However, Fanny's professionalism eventually undercuts this assertion: although she may be "serving", she can handle and maintain the large unwieldy car and navigate the unmapped battlefields, impressing the Russian colonel and earning his acceptance. Once in the citadel of Verdun, he feels both proud and protective as her employer.

The military citadel, located underneath the ruined town of Verdun, has been a male-only space for the duration of the war. Fanny's penetration of this space, like Bagnold's in 1919, symbolizes the prospective shift in gender balance precipitated by the Armistice. Like so many of the spaces through which Fanny passes, the citadel is filled with men of many nations. The officers sitting down to dinner are not only French, but also Russian and American. As a collective, they are astonished by the arrival of a woman in their midst. Despite their differences, Fanny remains unique. The place that has been saved for her is that of a "guest" at the top table, belying her actual position as a military driver and illustrating the complexity of gender in a world that has been exclusively male for so long. 
The ways in which the multiple racial communities stationed in France interact, as the war becomes part of memory, are one of the most powerful aspects of the novel. The silent battlefields that Fanny traverses and the towns in which she is billeted are filled with the peoples of many nations: French, German, British, Russian, American and Asian. Months earlier they all understood exactly how they should relate to each other, whether as friend, enemy or master. By 1919, the relationships are much more complex. Bagnold illustrates this lack of harmony through food-always so important to the soldier. Different armies have different rations. Fanny, as a driver with the war-impoverished French army, must subsist in the field on basic meat and potatoes. Many Russians have even less. But the Americans, so new to the war zone, have bacon chips, which they happily share with her. She defends the French with their inferior rations and is told: "Their fault for not kicking up a shindy" (83). But inequality breeds resentment, and the Americans are an unwelcome presence.

Fanny's status changes according to the nationality she is dealing with: "The Americans treat me as if I were an amusing child. The French, no matter how peculiar their advances, always as a woman" (126). Fanny, as an observer, documents these differences and begins to understand the lack of cohesion in the post-war world-a result less of war than of pre-existing conflicts. Set before the Paris Peace Conference 1919, but written with an understanding of its consequences, the novel anticipates later national antagonisms that might be at odds with the conventional legacy of disillusionment -a memory that foregrounds comradeship against a backdrop of disenchantment.

In post-war France, the appetite for communion is restricted. National differences are accentuated in the light of what now feels like an invasion:

"Go away!" said France restlessly, pushing at the new nations in her bosom. "It's all done. Go back again!"

"Are you an Ally?" said the Allies to each other balefully, their eyes no longer lit by battle, but irritable with disillusion-and each told his women tales of the other's shortcomings. (231)

We can feel the shadow of Paris here, as Bagnold is painfully aware of the national differences that were to impact so significantly on the prospects for lasting peace, as well as the ways in which the war was remembered. Towards the end of the novel, the narrative shifts away from Fanny's perspective, personifying these various countries and summarizing the sentiments that Fanny has heard repeatedly as she has come across men of different nations throughout the novel. The French dislike all other nationalities, the former allies who now appear as colonizers. "[E]yes no longer lit by battle" reflect only distrust as long-standing uncertainties re-emerge. Bagnold presents the war as a great leveller here, a source of unexpected harmony. 
Removed, the prospects for legacy take an unexpected turn, suggesting an alternative kind of disenchantment, born not of the war but of its end, which sits uncomfortably with cultural memory.

Bagnold also engages with the global and colonial legacy of the war:

Along the sides of the roads, in the gutters, picking the dust-heap of the battlefields, there were representatives of other nations who did not join in the intercriticism of the lords of the earth. Chinese, Arabs and Annamites made signs and gibbered, but none cared whether they were in amity or enmity. (231-32)

These subservient nationalities are not in France to fight the war, but to clean up after those who did the fighting. ${ }^{23}$ They make their own contribution to this Tower of Babel, unheard in the chaos as reconstruction begins, but waiting in the wings for a later day. Paul J. Bailey notes that "the story of Chinese contract workers seems to have disappeared down a historical black hole". ${ }^{24}$ While it cannot be said that Bagnold retrieves their stories, she articulates a prophetic awareness of the changes in store for the postwar world. Not only are we aware of the uncomfortable presence of these Asian workers, but they also imply alternative readings of the landscape and its inhabitants. According to Buck:

[Bagnold] renders alien through caricature these representatives of the routine exploitation of non-European labor by the British and French [...] these figures are surreal in their appearance, marked by gender uncertainty, and inhuman, with their language reduced to "screaming and twittering". Outsiders, with a precarious claim on humanity, they mark an alien space at the very center of Europe. $^{25}$

At the same time, however, this very "gender uncertainty", and failure to fit into the post-war landscape, brings to mind Fanny's own position. As Buck continues: "their foreignness aligns them with the other foreigner in the text-Fanny". ${ }^{26}$ Bagnold seems very aware of the national hierarchies at play and the problems they are likely to cause in the future, as European empires begin to crumble and different sets of winners and losers emerge.

Her representation of the German people is perhaps the most interesting. Fanny is billeted with a German family at Metz and travels into Germany as a driver, witnessing first-hand the multiple nations in the conquered land:

Only up in Germany was there any peace from acrimony. There the Allies walked contentedly about, fed well, looked kindly at each other. There were no epithets to fling-they had all been flung long ago.

And the German people, looking curiously back, begged buttons as souvenirs from the men who spoke so many different languages. (232)

It is ironic that there is peace in Germany. Yet this harmony is also found within communities of women. When Fanny is due to attend a ball, an eclectic group of women work together to ensure that her complicated dress is 
completed in time. Fanny's dressmaker is French, but her posting in Lorraine results in a multicultural community with many German residents. The dressmaker's German neighbours busily sew frills to ensure that the dress is ready on time. In the final crisis, when the bodice will not fasten, it is the German mother who covers it with cornflowers to hide the gap. This collective of women-French, German and English-works to help Fanny, as though there has been no war. This communion is absent from other mixed racial groups in the novel, all of which are male-perhaps suggesting something cohesive about female bonding. The lack of war brings the women together, while it pushes the men, deprived of a shared cause, apart.

The conclusion of a first world war should have led to racial and national harmonies, but, in the immediate post-war days, the opposite seems to be true. The "many different languages" symbolize this lack of cohesion. There is an almost nostalgic feeling for the times, so recently gone, when everyone understood his or her place. The different nationalities and all the soldiers have very quickly become an anachronism, as civilians reclaim the earth. And here, too, Bagnold suggests a different form of legacy-a future that may not be as bleak as received mythologies suggest.

The return of civilians to the town of Charleville marks the turning point for Fanny. In her final billet, with a whole house to herself, she has the personal space to begin to understand her own independence. It is a house that has been occupied by many foreigners since its owner fled following the deaths of her husband and son. Austrians, Turks, Bulgarians and Germans have all been there before Fanny. But while Fanny is conscious of these previous inhabitants, it is Philippe, the dead son whose possessions still fill the house, with whom she communes. It is in the paradox of his continuing presence and simultaneous absence that Bagnold begins really to explore ideas of memory. Philippe haunts the house through the remnants of his life, forcing Fanny to engage with him as a representative of the lost:

"It wasn't any use your learning German, was it Philippe?" she said, then stood frozen in conjecture as to the use and goal of all that bright treasure in his mind -his glass-blowing, his modelling, the cast head of a man she had found stamped with his initial, the things he had written and read, on slates, in books. "It was as much use his learning German as anything else," she said slowly, and her mind reeled at the edge of difficult questions. (255)

Sheffield associates the development of the culture of disillusionment in the 1920 s with the public realization and understanding of the actual number of military dead. ${ }^{27}$ Here, Bagnold captures that moment of realization in Fanny. However, rather than becoming disillusioned as a consequence, Fanny adopts Philippe as a companion in her solitude. The ways in which she imagines him are much more positive, more human. She pictures him living in the house and town as she does, having adventures similar to her 
own. In this fictionalization, he becomes complicit in her adaptation of the house to suit her needs:

Philippe was so powerless, he couldn't even stop his croquet hoop from being heated red-hot in the flames as a kettle-holder ... One must be sensible. He would allow it. That was the sort of device he would have thought well of. (258)

Even while she acknowledges the powerlessness of the dead, she begins to create a memory that incorporates their support of the living. Here, Philippe, the symbol of the lost, applauds her innovation, her spirit of adaptation and survival, which foregrounds an optimistic future.

This alternative way of constructing memory echoes the sentiments of $A$ Diary Without Dates. As I have noted, in A Diary Without Dates, Bagnold uses the seasons and the natural world to denote the passing of time in a way that overwrites the negative war experiences that might help to construct the culture of disillusionment:

Summer ... Can it be summer through whose hot air the guns shake and tremble? The honeysuckle, whose little stalks twinkled and shone that January night, has broken at each woody end into its crumbled flower.

Where is the frost, the snow? ... Where are the dead? (91)

The seasons seem almost to override the war by their insistence on continuing regardless. The honeysuckle, in contrast to the war, is permanent, adapting to each new challenge. The dead, like Philippe, fade. The living find ways of coping. Bagnold continues: "There is that in death that makes the throat contract and the heart catch: everything is written in water. We talk of tablets to the dead. There can be none but in the heart, and the heart fades" (91). The immediate trauma of the war and its dead is transient, like the seasons, "written in water". It is reliant on memory and memory fades, particularly the memory of the young who have much to live for. Fanny soon forgets Philippe as she anticipates the return of her French lover, Julien, now a civilian industrialist, who is coming to the town to inspect his factories. She knows he will return before the flowers that decorate her house, like Philippe, fade. But the dropping mimosa and willow palm also, perhaps appropriately, signify the end of her romance.

Fanny, like the narrator of A Diary Without Dates, has been able to pull a kind of victory from her war experience. She leaves us with happiness and a sense of optimism about the future-one in which women can move forward and develop their own lives. Lee's research into the legacy of the FANY supports this, suggesting that its members were

$[\ldots]$ groundbreaking in challenging the regulatory norms of gender and by living unconventional lives and doing work often coded as masculine. Through these subversive behaviours they were able to develop feminine stories of the war and claim the narrative authority of working alongside 
male combatants. Against the cultural myths of the time and in concert with the emerging legend of the FANY, these women "made themselves new" and imagined new cultural possibilities. ${ }^{28}$

Despite the misery that the women encounter in both Bagnold's war books, what is most memorable is the opportunity for liberation and self-discovery that these roles offer. The women are not disillusioned or disenchanted, as Bagnold herself was not. Equally, the multicultural communities of the post-war landscape are much more complex than might be expected with peace. These books adopt some of the accepted tropes of First World War writing and, in this way, have contributed to the cultural memory that is its legacy. But at the same time, alternative messages remain strong. This is what Hirsch and Smith mean when they write of "[w] terhistory that restores forgotten stories to the historical record". ${ }^{29}$ Their outsider positions allow them to see the war differently and, in so doing, offer an alternative way to remember-one that does not contribute to the one-dimensional version of the myth that still persists today.

\section{Notes}

1. Paul Fussell, The Great War and Modern Memory (Oxford: Oxford UP, 1977); Samuel Hynes, A War Imagined: The First World War and English Culture (London: Bodley, 1990); Janet S. K. Watson, Fighting Different Wars: Experience, Memory, and the First World War in Britain (Cambridge: Cambridge UP, 2004).

2. Rosa Maria Bracco, Merchants of Hope: British Middlebrow Writers of the First World War (Oxford: Berg, 1993), p. 76.

3. Claire M. Tylee, The Great War and Women's Consciousness: Images of Militarism and Womanhood in Women's Writings, 1914-64 (London: Palgrave, 1990); Sharon Ouditt, Fighting Forces, Writing Women: Identity and Ideology in the First World War (London: Routledge, 1994); Trudi Tate, Modernism, History and the First World War (Manchester: Manchester UP, 1998); Angela K. Smith, The Second Battlefield: Women, Modernism and the First World War (Manchester: Manchester UP, 2000).

4. Christine Hallett, Veiled Warriors: Allied Nurses of the First World War (Oxford: Oxford UP, 2014), p. 4.

5. Marianne Hirsch and Valerie Smith, "Feminism and Cultural Memory: An Introduction", Signs, 28.3 (2002): 1-19 (6).

6. Santanu Das, introduction, Race, Empire and First World War Writing, ed. Santanu Das (Cambridge: Cambridge UP, 2011), pp. 1-32 (4).

7. Claire Buck, Conceiving Strangeness in British First World War Writing (Basingstoke: Palgrave, 2015), p. 68.

8. Adrian Gregory, The Last Great War: British Society and the First World War (Oxford: Oxford UP, 2008), p. 250.

9. Gregory, p. 257.

10. Watson, p. 10.

11. Gary Sheffield, Forgotten Victory: The First World War: Myths and Realities (London: Headline, 2001), p. 10. 
12. Watson, p. 264.

13. Smith; Carol Acton, "Diverting the Gaze: The Unseen Text in Women's War Writing”, College Literature, 31.2 (2004): 53-79; Jane Potter, Boys in Khaki, Girls in Print: Women's Literary Responses to the Great War 1914-1918 (Oxford: Oxford UP, 2005).

14. Ouditt; Alison Fell and Christine Hallett, eds., Visions and Revisions: Studies in First World War Nursing (London: Routledge, 2013).

15. Janet Lee, War Girls: The First Aid Nursing Yeomanry in the First World War (Manchester: Manchester UP, 2005), p. 3.

16. Enid Bagnold, A Diary Without Dates (1918; London: Virago, 1978), p. 9. All subsequent citations are from this edition and are given parenthetically in the text.

17. Ellen La Motte, The Backwash of War (London: G. P. Puttnam's Sons, 1916); Mary Borden, The Forbidden Zone (London: William Heinemann, 1929). This is also the case in many private diaries and letters.

18. Anne Sebba, Enid Bagnold (1986; London: Faber, 2013), p. 65.

19. Stella Deen, "Enid Bagnold's The Happy Foreigner: The Wider World beyond Love", English Literature in Transition, 1880-1920, 44.2 (2001): 131-47 (132).

20. Lee, p. 211.

21. Enid Bagnold, The Happy Foreigner (1920; London: Virago, 1987), p. 65. All subsequent citations are from this edition and are given parenthetically in the text.

22. Susan Grayzel, Women's Identity at War: Gender, Motherhood, and Politics in Britain and France during the First World War (Chapel Hill: U of North Carolina P, 1999), p. 202.

23. Santanu Das notes that France recruited around 500,000 colonial troops during the war, including 140,000 Vietnamese. Together with Britain it also employed around 140,000 Chinese contract labourers (4).

24. Paul J. Bailey, “An Army of Workers: Chinese Indentured Labour in First World War France”, Das, pp. 35-52 (37).

25. Buck, pp. 71-72.

26. Buck, p. 72.

27. Sheffield, p. 6.

28. Lee, p. 243.

29. Hirsch and Smith, 7.

\section{Disclosure statement}

No potential conflict of interest was reported by the author.

\section{Notes on contributor}

Angela K. Smith is Associate Professor (Reader) in English at Plymouth University. She specializes in war writing, with a particular interest in the First World War and gender issues. She is the author of The Second Battlefield: Women, Modernism and the First World War (Manchester University Press, 2000) and editor of Women's Writing of the First World War: An Anthology (Manchester University Press, 2000). Her more recent book publications include, as general co-editor and volume editor, British Literature of World War I (Pickering and Chatto, 2011); 
Suffrage Discourse in Britain during the First World War (Ashgate, 2005); and, as editor, Gender and Warfare in the Twentieth Century: Textual Representations (Manchester University Press, 2004). Her latest collection, War and Displacement in the Twentieth Century: Global Conflicts, was published by Routledge in 2014 and her latest monograph, British Women of the Eastern Front: War, Writing and Experience in Serbia and Russia, 1914-20, was published by Manchester University Press in 2016. 